\begin{tabular}{|c|c|c|} 
Dinamika Journal, Vol. 1 No. 3, 2019 \\
ISSN ONLINE : 2686-2158 \\
Journal Homepage $:$ http://jurnal.lppm.unsoed.ac.id/ojs/index.php/dinamika
\end{tabular}

\title{
APLIKASI CABINET DRYER (PENGERING KABINET) UNTUK MENINGKATKAN PRODUKSI BAHAN BAKU PENGAWET ALAMI BUAH \\ KECOMBRANG (Etlingera elatior)
}

\author{
Rifda Naufalin $^{1) *}$, Rumpoko Wicaksono ${ }^{1)}$, Poppy Arsil ${ }^{1)}$ \\ ${ }^{1}$ Fakultas Pertanian, Unsoed \\ *Corresponding author: rifda.naufalin@unsoed.ac.id
}

Received 15 Oktober 2019; Accepted 26 Oktober 2019; Available online 30 Oktober 2019

\begin{abstract}
Abstrak
Perkembangan kesadaran masyarakat terhadap keamanan pangan menyebabkan munculnya tuntutan baru dari masyarakat yang menginginkan pangan yang lebih alami. Kondisi ini memberi peluang baru untuk mengembangkan dan memproduksi pengawet alami dari tanaman indigenus diantaranya kecombrang (Etlingera elatior). Program Pengembangan Usaha Produk Intelektual Kampus (PPUPIK) ini bertujuan untuk meningkatkan produksi pengawet alami pangan berbahan baku buah kecombrang yang bermutu dalam rangka menopang keamanan pangan. Metode yang digunakan adalah aplikasi prototipe pengering kabinet skala pilot plant untuk meningkatkan kapasitas produksi bahan baku pengawet alami, sehingga siap untuk dikomersialkan. Kegiatan PPUPIK dapat menghasilkan produk pengawet alami berbahan dasar kecombrang dengan mutu yang konsisten, kapasitas produksi meningkat dan meningkatkan efisiensi bahan baku.
\end{abstract}

Kata kunci : pengawet alami, pengering kabinet, buah kecombrang

\begin{abstract}
The development of public awareness of food safety has led to the demands from people who want more natural food. these conditions provide new opportunities to develop and produce natural preservatives plants namely kecombrang. This campus intellectual product development business program (PPUPIK) aims to increase the production of quality natural preservatives made from kecombrang fruit in order to support food security. the method used is the prototype dryer application so it is ready for commercial use. PPUPIK activities can produce natural preservatives made from kecombrang fruit with consistent quality, increased production capacity and increase the efficiency of raw materials
\end{abstract}

Keywords: nature preservative, cabinet dryer, kecombrang fruit

\section{PENDAHULUAN}

Perkembangan kesadaran masyarakat terhadap keamanan pangan menyebabkan munculnya tuntutan baru dari masyarakat yang menginginkan pangan yang lebih alami. Studi eksplorasi berbagai tanaman indigenus banyak dikembangkan untuk dapat menyediakan bahan pengawet alami. Kondisi ini memberi peluang baru untuk mengembangkan dan memproduksi pengawet alami, diantaranya pengawet alami dari tanaman kecombrang (Etlingera elatior). Kecombrang termasuk famili Zingiberaceae yang 
telah lama digunakan oleh masyarakat di daerah-daerah tertentu sebagai pemberi citarasa makanan.

Kecombrang memiliki komponen bioaktif yaitu flavonoid, fenolik, alkaloid dan triterpenoid. Ekstrak kecombrang terbukti memiliki aktivitas sebagai antimikroba dan antioksidan. Berdasarkan hal tersebut, telah dikembangkan pengawet alami berbahan baku kecombrang yang dapat diaplikasikan pada produk pangan. Pengawet alami dari kecombrang telah terbukti praktis dan stabil serta dapat menghambat pertumbuhan mikroba sehingga meningkatkan umur simpan produk pangan. Pengawet alami yang dihasilkan telah berhasil mengawetkan produk segar (buah, sayur, ikan, udang, daging), dan pada produk olahan (mie, tahu, sosis, bakso, nugget). Pengawet alami yang dihasilkan siap diaplikasikan ke Industri pangan. Produksi pengawet alami kecombrang sebagai alternatif pengganti pengawet sintetis berbahaya pada pangan dan memberi nilai tambah pada komoditas pertanian daerah misalnya tanaman kecombrang.

Proses produksi pengawet alami berbahan baku kecombrang dimulai dari pemilihan dan sortasi tanaman kecombrang, proses pengeringan. Kemampuan bunga kecombrang dapat dimaksimalkan dengan pengolahan lebih lanjut dengan dilakukan pengeringan. Pengeringan bertujuan untuk mengurangi kadar air pada bunga kecombrang sampai batas perkembangan mikroba dan kegiatan enzim yang dapat menyebabkan pembusukan terhambat atau bahkan terhenti sama sekali. Dengan demikian, bahan yang dikeringkan mempunyai waktu simpan lebih lama (Naufalin, 2017). Selama proses pengeringan, beberapa hal harus diperhatikan seperti suhu dan waktu pengeringan. Proses pengeringan peranan yang sangat penting. Jika suhu pengeringan terlalu tinggi akan mengakibatkan penurunan senyawa aktif dan perubahan warna produk yang dikeringkan. Sedangkan apabila suhu yang digunakan terlalu rendah sulit untuk mencapai kadar air yang diinginkan.

Pengolahan tanaman kecombrang menjadi pengawet alami sangat dipengaruhi oleh proses pengeringan, oleh karena itu melalui PPUPIK dikembangkan produksi pengawet alami dengan proses pengeringan menggunakan pengering kabinet. Proses pengeringan dengan pengering kabinet diharapkan dapat menghasilkan produk dengan kuantitas yang lebih banyak dan kualitas yang lebih baik dan seragam. Produk yang berkualitas tinggi dan seragam dapat dipergunakan sebagai pengawet alami yang dapat mengawetkan dan aman digunakan. Dengan demikian, kemungkinan memiliki peluang menggantikan pengawet sintetik yang berbahaya dan akan diminati oleh masyarakat, sehingga pemasaran produknya akan lebih besar dan meluas ke seluruh pelosok wilayah di Indonesia.

Kegiatan ini bertujuan menghasilkan bubuk pengawet alami berbahan baku buah kecombrang yang dapat diaplikasikan pada produk pangan, sehingga menjawab kebutuhan masyarakat terhadap kebutuhan Bahan Tambahan Pangan yang aman. Hal ini dilaksanakan melalui pengolahan bubuk kecombrang sebagai pengawet alami dengan penerapan teknologi pengering kabinet yang efisien dan hemat energi.

\section{METODE}

Kegiatan PPUPIK ini dilaksanakan selama 2 bulan di Pilot Plant Laboratorium Teknologi Pertanian Unsoed. Program PPUPIK ini dilaksanakan dengan mengaplikasikan teknologi pengering kabinet skala pilot plant yang telah diuji coba.

Bahan baku berupa tanaman kecombrang bagian buah kecombrang. Bahan baku diperoleh dari perkebunan petani di Kecamatan Sumbang, Kabupaten Banyumas. Peralatan yang diaplikasikan yaitu pengering kabinet dengan spesifikasi sebagai berikut: Dimensi : $1100 \times 600 \times 1800 \mathrm{~mm}$, Kapasitas : $10 \mathrm{~kg}$ bahan baku, Material : Mild Steell plate t1.2 mm, Frame mild steel plate, Laju pengeringan : 0,6 - $1 \%$ /jam, Fuel Consumption : LPG, 
Burner : LPG, Accesories : Rack dari Galvalum, Sistem Welding, Pintu type swing 2 pintu, Blower untuk Sirkulasi, Temperature Control dan Panel Box.

Pengambilan data dilakukan dengan menghitung kapasitas produksi sebelum dan sesudah aplikasi alat serta membandingkan kadar air dan mutu produk bubuk pengawet. Analisis data dilakukan dengan metode deskriptif.

\section{HASIL DAN PEMBAHASAN}

Teknologi pengolahan tanaman kecombrang menjadi produk pengawet alami meliputi tiga tahap yaitu tahap pembuatan bubuk, pengukuran kadar air, dan pengukuran kandungan fitokimia.

\section{Tahap pembuatan bubuk}

Buah kecombrang segar yang telah dipetik dari tanaman dibersihkan dengan air, ditiriskan, diiris kemudian dikeringkan dengan cabinet drier pada $50-70^{\circ} \mathrm{C}$ selama 4,5 dan 6 jam. Bahan yang telah kering kemudian dihancurkan dengan mesin giling sampai diperoleh bubuk yang homogen.

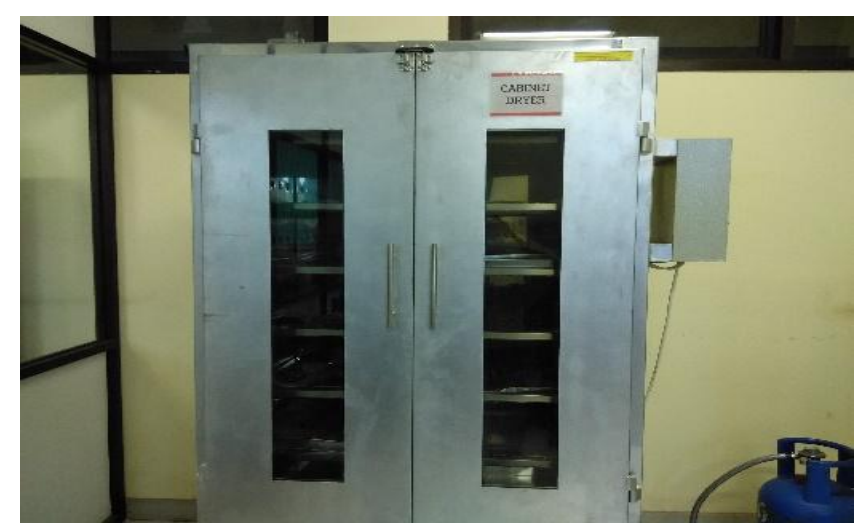

Gambar 1. Pengering Kabinet

\section{Pengukuran Kadar Air}

Sampel bubuk buah kecombrang ditimbang sebanyak 0,5 g dalam cawan moisture analyzer. Moisture analyzer diset pada suhu $105^{\circ} \mathrm{C}$. Moisture analyzer ditutup dan ditunggu hasil kadar airnya. Hasil kadar air dicatat.

\section{Pengujian Fitokimia Bubuk kecombrang}

Sampel bubuk buah kecombrang dilakukan pengujian kualitatif dengan melakukan uji flavonoid, Senyawa Fenolik, Alkaloid, Steroid/triterpenoid, Saponin, Tanin, dan Glikosida (Harborne, 1987). 
Nilai Rata-rata Kadar air bubuk buah kecombrang disajikan pada Tabel 1.

\begin{tabular}{cc}
\hline Suhu dan Waktu Pengeringan & Kadar Air Pengering Kabinet $(\%)$ \\
\hline $50^{\circ} \mathrm{C}, 4$ jam & 6,34 \\
$50^{\circ} \mathrm{C}, 5$ jam & 6,17 \\
$50^{\circ} \mathrm{C}, 6$ jam & 6,02 \\
$60^{\circ} \mathrm{C}, 4$ jam & 6,23 \\
$60^{\circ} \mathrm{C}, 5$ jam & 6,18 \\
$60^{\circ} \mathrm{C}, 6$ jam & 5,69 \\
$70^{\circ} \mathrm{C}, 4$ jam & 6,17 \\
$70^{\circ} \mathrm{C}, 5$ jam & 6,08 \\
$70^{\circ} \mathrm{C}, 6$ jam & 5,46 \\
\hline
\end{tabular}

Keterangan : Data hasil pengamatan (2019)

Pada Tabel 1 menunjukkan bahwa produk bubuk pengawet alami berbahan buah kecombrang dengan proses pengeringan menggunakan pengering kabinet kapasitas $10 \mathrm{~kg}$ menghasilkan produk dengan dengan kadar air yang lebih rendah dibanding dengan penggunaan pengering oven kapasitas $1 \mathrm{~kg}$. Hal ini karena pengering kabinet terdapat blower yang berfungsi menghembuskan uap panas, sehingga dapat mengeringkan produk yang lebih efisien.

Berdasarkan Tabel 1 diperoleh hasil kadar air dari seluruh perlakuan telah memenuhi persyaratan sebagai bubuk sebagai bahan baku pengawet dengan kandungan kadar air yang tidak melebihi 10\%. Menurunnya kadar air pada buah kecombrang dipengaruhi oleh penguapan air akibat dari suhu dan waktu pengeringan (Yamin et al., 2017). Semakin lama proses pengeringan menyebabkan penguapan air yang terdapat pada bunga kecombrang semakin tinggi sehingga kadar air yang terdapat pada daun kecombrang semakin rendah. Hal ini didukung oleh pernyataan Widjanarko (2012), laju penguapan disamping dipengaruhi oleh tingkat kelembaban juga dipengaruhi oleh suhu di sekitar bahan yang dikeringkan ( [1]).

Tabel 2. Analisis fitokimia bubuk buah kecombrang

\begin{tabular}{|c|c|c|c|c|c|c|c|}
\hline Perlakuan & Fenol & Flavanoid & Tanin & Saponin & Steroid & Alkaloid & Glikosida \\
\hline $50^{\circ} \mathrm{C}, 4 \mathrm{jam}$ & +++ & ++ & +++ & ++ & +++ & ++++ & - \\
\hline $50^{\circ} \mathrm{C}, 5 \mathrm{jam}$ & +++ & +++ & +++ & ++ & +++ & +++ & - \\
\hline $50^{\circ} \mathrm{C}, 6 \mathrm{jam}$ & +++ & ++ & +++ & +++ & +++ & +++ & - \\
\hline $60^{\circ} \mathrm{C}, 4 \mathrm{jam}$ & ++++ & +++ & +++ & ++ & +++ & +++ & - \\
\hline $60^{\circ} \mathrm{C}, 5 \mathrm{jam}$ & +++ & +++ & +++ & +++ & +++ & +++ & - \\
\hline $60^{\circ} \mathrm{C}, 6 \mathrm{jam}$ & +++ & ++ & +++ & +++ & ++ & ++ & - \\
\hline $70^{\circ} \mathrm{C}, 4 \mathrm{jam}$ & +++ & ++ & +++ & +++ & +++ & +++ & - \\
\hline $70^{\circ} \mathrm{C}, 5 \mathrm{jam}$ & ++ & ++ & +++ & ++ & +++ & ++ & - \\
\hline $70^{\circ} \mathrm{C}, 6 \mathrm{jam}$ & +++ & ++ & +++ & +++ & +++ & +++ & - \\
\hline \multicolumn{8}{|c|}{$\begin{array}{c}\text { Keterangan: }- \text { (negatif), }+ \text { (positif lemah), }++ \text { (positif), }+++ \text { (positif kuat), }++++(\text { positi } \\
\text { kuat sekali) }\end{array}$} \\
\hline $\begin{array}{r}\text { Berda } \\
\text { komponen fit } \\
\text { Damp } \\
\text { kecombrang }\end{array}$ & $\begin{array}{l}\text { rkan } \\
\text { imia y } \\
\text { PPUF } \\
\text { an me }\end{array}$ & $\begin{array}{l}\text { halisis fitok } \\
\text { ag dapat ber } \\
\text { K pada pros } \\
\text { berikan mar }\end{array}$ & $\begin{array}{l}\text { mia, bu } \\
\text { ingsi seb } \\
\text { pmbua } \\
\text { aat yang }\end{array}$ & $\begin{array}{l}\text { uk buah } \\
\text { gai pengav } \\
\text { in bubuk p } \\
\text { sangat pos }\end{array}$ & $\begin{array}{l}\text { kecombr } \\
\text { et alami. } \\
\text { ngawet a } \\
\text { if. Bebe }\end{array}$ & $\begin{array}{l}\text { Ig masih } \\
\text { mi berbah } \\
\text { pa Nilai t }\end{array}$ & $\begin{array}{l}\text { mengandun } \\
\text { n dasar bual } \\
\text { mbah produ }\end{array}$ \\
\hline
\end{tabular}


dari sisi Ipteks adalah meningkatkan daya kompetetif pengawet alami yang pada akhirnya akan menjadi unit usaha di Universitas Jenderal Soedirman, semakin meningkatkan kegiatan usaha khususnya usaha berbasis teknologi pangan, yaitu Bahan tambahan pangan (BTP), semakin meningkatkan pendapatan petani kecombrang, semula tanaman kecombrang belum dimanfaatkan akan menjadi produk bernilai ekonomis dan semakin terbukanya usaha baru, produk pengawet alami dapat dipakai untuk mengawetkan produk pangan, sehingga akan menarik minat konsumen dan produk pengawet alami merupakan produk pengawet dengan bahan baku sumber daya asli Indonesia.

\section{KESIMPULAN}

Program Pengabdian kepada Masyarakat PPUPIK produksi bubuk pengawet alami berbahan baku buah kecombrang dengan aplikasi pengering kabinet menghasilkan produk yang memenuhi persyaratan kadar air, serta masih memiliki komponen bioaktif yaitu fitokimia yang berfungsi sebagai pengawet alami, sehingga berdampak positif sebagai suatu usaha pengawet alami yang mampu berkompetisi dengan BTP pesaing.

\section{UCAPAN TERIMAKASIH}

Tim pelaksana mengucapkan terima kasih kepada Direktorat Riset dan Pengabdian kepada Masyarakat Dikti melalui Lembaga Penelitian dan Pengabdian kepada Masyarakat Unsoed atas pendanaannya dengan Skim Program Pengembangan Usaha Produk Intelektual Kampus (PPUPIK) 2019.

\section{DAFTAR PUSTAKA}

Naufalin, R. 2005. Kajian Sifat Antimikroba Bunga Kecombrang (Nicolaia speciosa Horan) Terhadap Berbagai Mikroba Patogen dan Perusak Pangan. Disertasi, Program Pascasarjana Ilmu Pangan IPB, Bogor.

Naufalin, R., Jenie, B.S.L., S.R. Herastuti. 2005a. Identification and Antimicrobial Activity of the Essential Oils of Nicolaia speciosa Horan (Kecombrang). Proceeding Asean Food Conference Jakarta, August 2005.

Naufalin, R., Jenie, B.S.L., S.R. Herastuti. 2005b. Kajian Sifat Antimikroba Bunga Kecombrang (Nicolaia speciosa Horan) Terhadap Berbagai Mikroba Patogen dan Peruses Pangan. Jurnal Tekn \& Industri Pangan. XII (3).

Naufalin, R., Jenie, B.S.L., S.R. Herastuti. 2006. Kajian Sifat Antimikroba Komponen Aktif Kecombrang (Nicolaia speciosa Horan) Terhadap Berbagai Mikroba Patogen dan Perusak Pangan. Laporan Hibah Bersaing Tahun III. DP2M Dikti, Jakarta.

Naufalin, R. 2008. Aktivitas dan Mekanisme Kerja Antibakteri Ekstrak Bunga Kecombrang (Nicolaia speciosa Horan). Makalah Seminar Nasional Perhimpunan Mikrobiologi Indonesia, Purwokerto 22-23 Agustus 2008.

Naufalin, R., Erminawati. 2009. Pemanfaatan ekstrak rempah-rempah sebagai pengawet alami pada mie. Prosiding seminar Perhimpunan Ahli Teknologi Pangan. Jakarta, 3-4 Nopember 2009.

Naufalin, R., Herastuti, S.R., Erminawati. 2010. Potensi Bunga Kecombrang Sebagai pengawet Alami pada Tahu dan Ikan. Prosiding Seminar Nasional Peran Keamanan 
Pangan Produk Unggulan Daerah Dalam Menunjang Ketahanan Pangan dan Menekan Laju Inflasi. Purwokerto, 8-9 Oktober 2010.

Naufalin, R., S.R. Herastuti. 2010. Application of the inner part of kecombrang stem (Nicolaia speciosa) as a nature preservative on meat-balls and nugget. Proseeding Internasional Conference Nutraceutical and Functional Foods. Bali, 12-15 October 2010.

Naufalin, R., S.R. Herastuti. 2011. Potensi Antioksidan Hasil Ekstraksi Tanaman Kecombrang (Nicolaia speciosa) Selama Penyimpanan. Prosiding Seminar Nasional membangun Daya Saing Produk Pangan Berbasis Bahan Lokal. Surakarta, 8 Juni 2011.

Naufalin, R., S.R. Herastuti. 2012. Pengawet Alami Pada Produk Pangan. UPT. Percetakan dan Penerbitan Universitas Jenderal Soedirman, Puwokerto.

Naufalin, R., S.R. Herastuti. 2013a. Microcapsule application of kecombrang flower extract: effect of concentration, type of fraction, $\mathrm{pH}$ of medium and $\mathrm{NaCl}$ on microbiological properties of minced beef. Journal Animal Production 15 (1):8-14.

Naufalin, R., S.R. Herastuti. 2013b. Nanoenkapsulasi Ekstrak Kecombrang (Nicolaia speciosa Horan) dan Penerapannya Pada Produk Pangan. Laporan Hasil Penelitian Hibah Kompetensi Tahun II. DP2M Dikti, Jakarta.

Naufalin, R., S.R. Herastuti. 2013c. Nanoencapsulated of Natural Antioxidant Based On Kecombrang (Nicolaia speciosa) Fruit Using Cyclodextrin-Gelatin as Filler Ingredient. Proseeding Asean Food Conference. Singapore, 9-11 September 2013.

Naufalin, R,. S.R. Herastuti. 2014. Nanoenkapsulasi Ekstrak Kecombrang (Nicolaia speciosa Horan) dan Penerapannya Pada Produk Pangan. Laporan Hasil Penelitian Hibah Kompetensi Tahun III. DP2M Dikti, Jakarta.

Naufalin, R. 2017. Kecombrang Antimikroba dan Pemanfaatannya Sebagai Pengawet Pangan. Universitas Jenderal Soedirman, Purwokerto.

Widjanarko, A. 2012." Hubungan anemia dengan pengetahuan gizi, konsumsi Fe, Protein, Vitamin C, dan pola haid pada mahasiswa putri" dalam media gizi mikro Indonesia. Jurnal Balai Penelitian dan Pengembangan kesehatan (Balitbangkes). Vol. 4(2): 5158

Yamin, M., D.F Ayu., \& F. Hamzah. 2017. Lama pengeringan terhadap aktivitas antioksidan mutu teh herbal daun ketepeng cina (Cassia alata L.). Jurnal Faperta. Vol. 4(2): 5. 